\title{
SMOKING IS UNLAWFUL IN ISLAM
}

\author{
By Ibrahim B. Syed, Sc.D., F.A.C.R., F.Inst.P., F.A.I.C., F.R.S.H. \\ Clinical Professor of Medicine \\ Professor of Nuclear Medicine Technology \\ University of Louisville School of Medicine \\ Carmichael Building \\ Louisville, Kentucky 40292
}

\section{SUMMARY}

Cigarette smoking is the most widespread example of drug dependence in the United States and in all the Islamic countries as well. The U.S. Surgeon General's Office considers cigarette smoking to be America's worst drug addiction problem. Medical investigations show that cigarette smoking is a major factor in the development of many cases of cancer, heart trouble, chronic lung and respiratory diseases and other ailments. Smoking causes more illnesses and death than all other drugs. Cigarette smoking by pregnant women results in deleterious health effects on their newborn children. These findings and the revelations in the Holy Qur'an clearly prohibit smoking of tobacco by Muslims. Hence smoking is considered unlawful in Islam.

\section{Smoking and Health Effects}

It is very well known that cigarette smoking is the most widespread example of drug dependence in the United States. A pamphlet released by the U.S. Surgeon General's Office entitled "Why People Smoke Cigarettes"' calls cigarette smoking America's worst drug addiction problem. It involves addiction to the drug nicotine in tobacco and possible other tobacco substances.

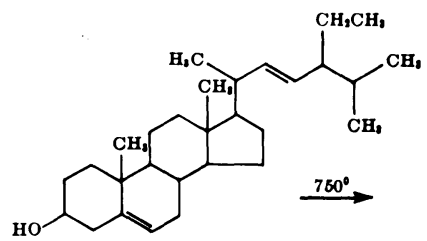

Stigmasterol

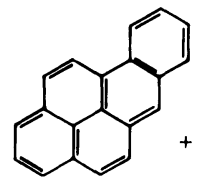

Benzo(s)pyrene

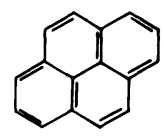

Pyrene
Figure 1

\begin{tabular}{|c|c|c|}
\hline Compound & $\begin{array}{l}\text { Relative activity as } \\
\text { complete carcinogen }\end{array}$ & $\mathrm{Ng}$ / cigarette \\
\hline Beneola $a$ pyrene & $++t$ & $10-60$ \\
\hline 6-Methylchrysene & +++ & 0.6 \\
\hline Dibens $[a, h]$ anthracene & ++ & 40 \\
\hline Benzo( $b$ ) fuoranthene & ++ & 80 \\
\hline Benzo[jfluoranthene & ++ & $\infty$ \\
\hline Dibeneof $(a, h)$ pyrene & ++ & קper \\
\hline Dibeneod $a, i$ pyrene & ++ & $p$ \\
\hline Dibeng $(a, j)$ ecridine & ++ & $8-10$ \\
\hline Indeno $[1,2, s-c, d]$ pyrene & + & 4 \\
\hline Beneod cl phenanthrene & + & "לpp \\
\hline Bensy a anthracene & + & $40-70$ \\
\hline Chryiene & $+?$ & $40-60$ \\
\hline Beneo[e]pyrene & & $b-40$ \\
\hline 2, 2-Methylchryvene & $+?$ & 7 \\
\hline 1-, Q-Methylchrysene & - & 10 \\
\hline 2-Methylfuoran thene & + & 34 \\
\hline 8-Methylfinoranthene & ? & 40 \\
\hline Dibenz $\{a$, janthracene & $(+)$ & $p$ \\
\hline Dibenef $a, h$ \}acridine & $(+)$ & 0.1 \\
\hline Dibeneod $(c, g)$ carbarole & $(+)$ & 0.7 \\
\hline
\end{tabular}

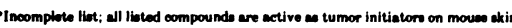

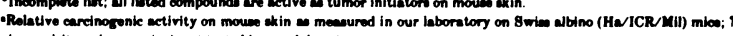

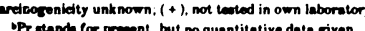

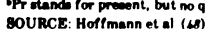

An authoritative British report ${ }^{1}$ stated that tobacco smoking is a form of drug dependence different from but no less strong than that of other addictive drugs - the most stable and well-adjusted person will, if he smokes at all, almost inevitably become dependent on the habit.

An Australian government report of 1977 called Drug Problems in Australia - An Intoxicated Society", says, "It is important to recognize that smoking is a form of drug dependence, but one with especially insidious characteristics."

Like many other drugs, the chemicals in cigarettes affect the chemistry of the brain and nervous system and create dependence and lead to compulsive use.

More than 56 million Americans and multiple scores of millions more in other nations, including Islamic nations ${ }^{3}$ are hooked on cigarettes in the same way as caffeine addicts are hooked on caffeine. A major reason why sales continue at high levels despite widespread public knowledge about the health hazards is the addictive nature of cigarettes.

\begin{tabular}{|c|c|c|c|c|c|}
\hline Number of packs per day & $\begin{array}{l}\text { British } \\
\text { doctors }\end{array}$ & $\underset{\text { States }}{\text { Men in } 9}$ & $\begin{array}{c}\text { U.8. } \\
\text { veterans }\end{array}$ & $\underset{\text { veterans }}{\text { Canadian }}$ & $\underset{\text { Btates }}{\text { Men In } 25}$ \\
\hline $\begin{array}{l}<1 / 2 \\
3,1-1 \\
1-2 \\
\text { over } 2\end{array}$ & $\begin{array}{r}1.0 \\
1.5 \\
11.7\end{array}$ & $\begin{array}{l}1.2 \\
1.9 \\
2.1 \\
2.4\end{array}$ & $\begin{array}{l}1.3 \\
1.8 \\
1.7 \\
1.9\end{array}$ & $\begin{array}{r}1.7 \\
11.7 \\
120\end{array}$ & $\begin{array}{l}1.3 \\
2.0 \\
2.1 \\
2.3\end{array}$ \\
\hline
\end{tabular}

\begin{tabular}{|c|c|c|c|c|}
\hline Number of pecks per day & $\begin{array}{l}\text { British } \\
\text { doctors }\end{array}$ & $\begin{array}{l}\text { Men in } \\
\text { Oftates }\end{array}$ & $\underset{\text { vetserans }}{\text { U.s. }}$ & $\begin{array}{c}\text { Canadian } \\
\text { veterans }\end{array}$ \\
\hline $\begin{array}{l}\text { <3 } \\
3,-1 \\
1-2\end{array}$ Over $2 \ldots$ & $\begin{array}{r}4.4 \\
10.8 \\
143.7\end{array}$ & \begin{tabular}{r|}
6.8 \\
7.8 \\
16.9 \\
21.7
\end{tabular} & $\begin{array}{r}8.2 \\
98.1 \\
18.1 \\
20.8\end{array}$ & 11 \\
\hline
\end{tabular}

Over one pack.

TABLE III

Most people start smoking just to conform to peer or social pressures. They get a feeling of "grown up." They find smoking (nicotine) at first acts as a stimulant. Later they find they need to smoke as a tranquilizer. These smokers develop a level of tolerance and bodily adjustment to nicotine. If this level of nicotine is not maintained in their blood, they will experience uncomfortable physical-psychological dependence problems. These uncomfortable feelings are classic drug withdrawal symptoms. Addictive drugs are psychoactive which create brain and nervous system dependence and lead to compulsive use. Abrupt discontinuation leads to physiological and psychological distress. The withdrawal symptoms are headache, stomach discomfort, nervousness, irritability, sweating, change in heart and blood pressure and lower excretion of some hormones affecting the nervous system. ${ }^{4}$ 
The U.S. Surgeon General, C. Everett Coop, says "Cigarette smoking is clearly identified as the chief preventable cause of death $(340,000$ deaths per year in U.S.A.) in our society. It is a major factor in the development of many cases of cancer, heart trouble, chronic lung and respiratory diseases and other ailments. Smoking causes more illnesses and death than all the other drugs." 5

\begin{tabular}{|c|c|c|c|c|c|c|}
\hline \multirow{3}{*}{ Causes of death } & \multicolumn{3}{|c|}{ One pack or less } & \multicolumn{3}{|c|}{ More than one peck } \\
\hline & \multicolumn{2}{|c|}{ Number of deaths } & \multirow{2}{*}{$\underset{\text { ratio }}{\text { Mortality }}$} & \multicolumn{2}{|c|}{ Number of deaths } & \multirow{2}{*}{$\underset{\text { ratlo }}{\text { Mortallty }}$} \\
\hline & Expected & Observed & & Expected & Obeerved & \\
\hline 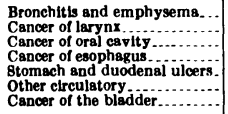 & $\begin{array}{r}44.6 \\
3.6 \\
16.8 \\
13.2 \\
32.5 \\
98.5 \\
57.3\end{array}$ & $\begin{array}{r}225 \\
19 \\
63 \\
40 \\
110 \\
263 \\
80\end{array}$ & $\begin{array}{l}\text { 5. } \\
\text { 3. } \\
3.2 \\
3.0 \\
\text { 3.4 } \\
2.6 \\
1.4\end{array}$ & $\begin{aligned} 17.2 \\
4.1 \\
14.8 \\
91.7 \\
31.2 \\
00.4 \\
23.7\end{aligned}$ & $\begin{array}{r}147 \\
81 \\
60 \\
48 \\
91 \\
175 \\
73\end{array}$ & $\begin{array}{l}8.5 \\
7.6 \\
4.1 \\
4.8 \\
2.8 \\
2.8 \\
3.1\end{array}$ \\
\hline
\end{tabular}

TABLE IV

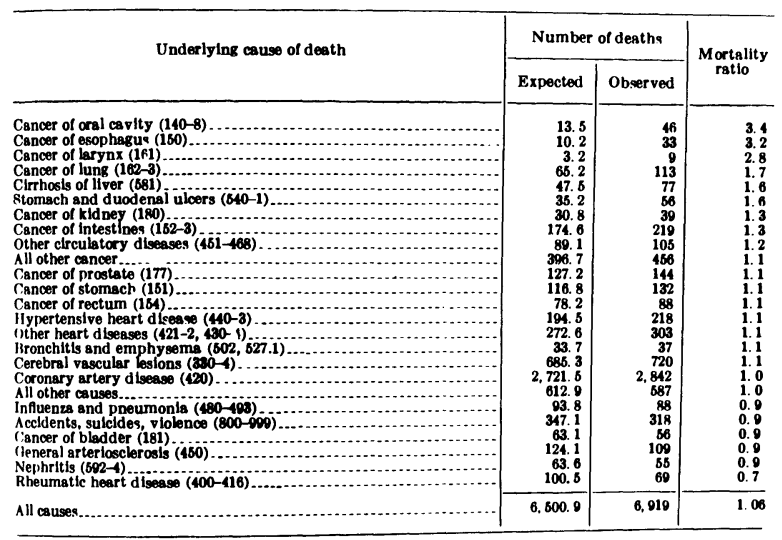

+Includes Brittsh doctors, men in 9 States, U.8. veterans, Canadlan veterans, and men in 25 States; +Includes Britlsh doctors, men in 9 States, U.8. veterans, Canadlan veterans,
includes ex-smokers for men in 9 States; excludes pipe smokers for Canad lan veterans.

TABLE V

\section{Smoking and Islam}

In Islam cleanliness and hygiene are emphasized to the extent that it has been considered a part of Iman (faith). It is very well known that a smoker's mouth is unclean and foul smelling "like a cigarette ash-tray." Allah says:

"And forbids them what is bad."

$$
\text { Al-Araf, VII: } 157
$$

"O ye who believe ! intoxicants and gambling are an abomination of satan's handiwork. Eschew such abominations that ye may prosper."

Al Ma'idah, V: 93

The word intoxicant has three meanings: ${ }^{6}$

(1) To induce, especially the effect of ingested alcohol.

(2) To stimulate or excite.

(3) To poison.

Except the first meaning the latter two are very well valid and both applicable to nicotine and caffeine.
Smoking is nothing but a form of slow suicide. The Qur'an says:

"And slay not the life which Allah hath forbidden..."

Al-Isra, XVII: 33

"And make not your own hands contribute to your destruction."

Al-Baqarah, II: 195

"Nor kill or destroy yourselves for verily Allah hath been to you most Merciful.",

An-Nisa, IV:29

The Prophet of Allah (peace be upon him) has said:

"Nor be hurted or injure others."

It is scientifically proven that the exhaled smoke of the smoker is hazardous to non-smokers around him.

The amount of money a smoker spends on cigarette smoking in a period of $\mathbf{3 0}$ years is calculated to be Two Hundred Thousand Dollars or more. All this money is simply wasted (not including the money spent on smoker's health care). Allah says:

"But squander not your wealth in the manner of a spend thrift, verily spendthrifts are brothers of evils."

\section{Al-Isra, XVII: 26,27}

Body is polluted by smoking. Hence smokers cannot pray until they have cleansed themselves. According to the Qur'an:

"O ye who believe! Draw not near unto prayer when you are drunken, till ye know that which ye

utter, nor when you are polluted save when journeying upon the road, till you have bathed."

An-Nisa, XV: 43

The Christians consider the human body to be a sacred trust given to man by God because it contains the spirit breathed into it by God. Hence the physical body should not be polluted or injured or destroyed in any way by smoking or by taking of alcohol or any type of habit forming drugs.

\section{CONCLUSION}

For the foregoing reasons and for reasons considered elsewhere ${ }^{7}$ smoking is regarded as unlawful in Islam. Hence smoking should be discouraged in all Islamic countries and banned if possible.

All smoking Muslims should give up this unhealthy and un-Islamic activity. The best way to give it up is to stop all smoking completely. Tapering off on the amount one smokes does not work for most people. It is not easy to quit suddenly, but it is presently the most successful way. For the Muslims who sincerely practice Islam and who submit themselves to the Will of Allah, this should not be a difficult task. 


\section{For reprints contact:}

Dr. Ibrahim B. Syed

V. A. Medical Center

800 Zorn Avenue

Louisville, KY 40202, U.S.A.

\section{References}

1. The Royal College of Physicians, Smoking or Health, Third Report, 1977, p. 98.

2. Drug Problems in Australia: An Intoxicated Society? A Report from the Senate Standing Committee on Social Welfare. Australian Government Publishing Service, Canberra, Australia, 1977.

3. Taha A.: Smoking and Muslim Countries: The immediate and serious threat. J.I.M.A.; 14: 50-52, 1982.

4. Jaffee J. H., Drug Addiction and Drug Abuse (Ch. 16), Clinical Characteristics: Nicotine. In: The Pharmacological Basis of Therapeutics. Goodman LS and Gilman A (Editors), MacMillan Pub. Co., Inc., New York, 1975, p. 305.

5. The Health Consequences of Smoking. The Changing Cigarette - A Report of the Surgeon General. U.S. Department of Health and Human Services, P.H.S., Rockville, Maryland, 1981, DHHS (PHS) 81-50156.

6. The American Heritage Dictionary of the English Language. Houghton Mifflin Co., Boston, 1978, p. 686.

7. Yusuf Al Qaradawi, Al Halal Wal Haram, Cairo, 1960. 